\title{
Influence of Marketing Mix Strategy in Insurance Business: The Case of Kota Bharu
}

\author{
M.S. Che Rusuli ${ }^{1}$, R. Ruwaida ${ }^{1}$, M. Noraani ${ }^{1}$, J. Takala $^{2}$ \& M. Nizamuddin ${ }^{3}$ \\ ${ }^{1}$ Malaysian Graduate School of Entrepreneurship and Business, Universiti Malaysia Kelantan, Kampus Kota, \\ Kelantan, Malaysia \\ ${ }^{2}$ Faculty of Technology, University of Vaasa, Finland \\ ${ }^{3}$ Faculty of Entrepreneurship \& Business, Universiti Malaysia Kelantan, Kampus kota, Kelantan, Malaysia \\ Correspondence: M.S. Che Rusuli, Malaysian Graduate School of Entrepreneurship and Business, Universiti \\ Malaysia Kelantan, Kampus Kota, 16100 Pengkalan Chepa, Kelantan, Malaysia.
}

Received: May 1, 2019

doi:10.5430/rwe.v10n2p88
Accepted: June 1, 2019

Online Published: July 8, 2019

URL: https://doi.org/10.5430/rwe.v10n2p88

\begin{abstract}
Malaysia has experience a low penetration for Takaful business despite many growing operators in insurance industry. After 25 years in operation, it is time that Takaful industry is evaluated in terms of its performance. This study provides better understanding on Takaful customer satisfaction in a case of Kota Bharu. Population of this study are customers who have subscribing family Takaful plans in selected Takaful operator at least one years' experience based on convenience sampling method. A total of 196 questionnaires were distributed and 163 questionnaires were returned. Therefore, this study revealed that the Product, Pricing, Promotion, People and Process towards Takaful operator were positively influence customer satisfaction. Finally, the study found that the Process indicates as the most critical factor that influences customer satisfaction toward Takaful Operator.
\end{abstract}

Keywords: customer, satisfaction, marketing mix strategy, insurance industry

\section{Introduction}

Nowadays, Takaful industry has become more diversified internationally and locally as there has been a significant increase in the number of Takaful operators operating worldwide including Malaysia. Takaful operator is the Takaful fund administrators or known as organizations managing funds in trust on behalf of the participants. There is a contract between Takaful operator and the participants are under the Wakalah (agency) or Mudharabah (profit-sharing) (Hassan et al., 2018). The increase number of Takaful Operators in Malaysia encourage a good opportunities for the expansion of the Takaful market share and increased penetration. There are two types of Takaful businesses such as General Takaful and Family Takaful (Masud, 2010; Khan \& Adnan Hye 2014). According to Cheikh (2013), General Takaful focuses on short-term property and liability protection against any loss or damage. There are many types of protection offered such as fire and theft, motor-vehicle, marine, personal accident, employer's liability and workers compensation. The participant determines the amount he or she want to guarantee, and pays his Takaful contribution to the Takaful operators. On the other, Kaunain and Akhtar (2016) stated that, the Family Takaful focuses on combination of long-term protection and savings for participants and dependents arising from disability, survival or death. This is an investment program to provide halah investments (which are considered to Shariah) returns to participants as well as joint financial aid. Individuals take part in regular residual money to provide supportive financial assistance their dependents if they early death, or as a contingency savings if they are having permanent disability or still alive until maturity date of the policy plan.

The global Takaful industry has seen impressive growth, especially since the last seven years. Nevertheless, the performance of the Takaful industry in Malaysia is still lagging behind in terms of total insurances market penetration and share. According to RAM Rating Services Berhad analytical, in their publication on 31 March 2017, they expect the growth trajectory of Takaful sector to remain higher than conventional insurances by the growth of family Takaful segment. However, they founded that only 15\% of 31.19 million Malaysians in the family Takaful penetration rate. There are substantially lower than relative life insurance's $41 \%$. This fact shows that there is a huge potential untapped market for the Takaful industry (Ying, 2017). The Malaysian government has instructed Bank 
Negara Malaysia (Central Bank of Malaysia) to play an important role in introducing and promoting Takaful business by providing better financial infrastructure. By referring to the Bank Negara Malaysia Report (2017), business performance is evidence of Takaful and conventional insurance growth. The total business performance in term of contribution income for both Takaful and conventional insurance are increased from year to year but, there are significant differences between their businesses (Khan \& Ali 2017).

The contribution income for the Takaful business are increased from RM17.0 million in 2011 to RM26.8 million in 2016. Similarly, for conventional insurance businesses are increased at a higher space which from RM36.4 million in 2011 to RM48.7 million in 2016. In terms of the contribution income for the Insurance and Takaful business, it can be concluded that the Takaful fund asset was far behind the conventional insurance. Currently, the performance improvement mechanism in the Takaful industry focuses on customer satisfaction, demand and interest. Customers' satisfaction is regarded as a factor of growth, profitability and development as well as Takaful operator achievement. As a key indicator, the number of customers subscribing family Takaful plans will affect the fund assets of Takaful operator for every year. In challenging industry environment, Takaful operators needs to take appropriate measures to ensure that company remains competitive advantage and will sustain in marketplace with new innovative ways of Takaful business.

This study aims to fill the massive gap and hope it will provide insightful finding to all Takaful operator in Malaysia, especially in Kota Bharu on determining the customers satisfaction level and the critical factors that influencing customer satisfaction towards Takaful operator. This study will also analyze the relationship of five components in Marketing Mix strategies and customer satisfaction. Therefore, this study develops three (3) main objectives as below:

1). To identify the customer satisfaction level towards Takaful operator.

2). To assess the relationship among Product, Pricing, Promotion, People, Process and customer satisfaction towards Takaful operator.

3). To determine the most critical factor that influences customer satisfaction towards Takaful operator.

\section{Related Works}

Organizations that using the marketing mix in their business will help them increase the organization's sales and profits, thus reaching their optimal marketing level (Sahni, 2017; Bay, Petrizzi and Gill, 2008). The elements in marketing mix namely as Product, Price, Place, and Promotion (4P) are controllable tools that reflect customer's demand and satisfaction. On the other hand, holistic marketing acknowledges that everything matters in marketing and that a broad, integrated perspective is often necessary (Pomering \& Johnson, 2018). Understanding and execution of elements in the marketing mix will help service providers to influence potential and existing customers to continue to do business and become loyal customers to their products and services (Nandi et al., 2013; Khan, et.al 2018). In this context, Takaful industry use marketing mix elements to investigate factors that can bring customer satisfaction to subscribe family Takaful product instead of other competitors.

\subsection{Product}

Preceding studies done by Muala and Qurneh (2012) and Goi (2011) stated that 'Products' are good or services offered by companies in the market. Products can be classified "as something or anything that can be offered to the customers for attention, acquisition or consumption and satisfies some want and need". It consists of ideas, physical objects, people, places, services or organizations. Marketers need to build real products around core products and then build augmented products around core and actual products. Core products refer to service of problem solving or core benefits that customers get when they purchase some products, instead of actual products refer to product parts, design, features, brand names, packaging, levels quality and other features combined in others to deliver key benefits. Augmented products mean connecting additional services and benefits around core and actual products. This additional factor can guarantee after-sales service, installation and so on (Riaz \& Tanveer, 2011; Kip'ngetich, Osman $\&$ Ali 2018). Products one of the key in marketing mix strategy whereby retailers can differentiate their products by offer unique features from competitors. The quality, features, brands and designs characterize the product. As such, good customer acceptance of the product is based on the benefits of the products that they received and the design that suits with them. Hence, pre-and post-sales services are an integral part of the product package and it could contribute to improved company performance. 


\subsection{Price}

Price is seen as the most important factor affecting user choice (Aziz, Md Husin, Hussin, \& Afaq, 2019; Mohammed Kamil, Subramaniam, Ali, Musah, \& Alex, 2018). Prices are the only variables in the marketing mix that must be fixed in relation to the other Ps and the most important elements as it is the only revenue-generating mix for the organization. Previous researchers (e.g. Muala and Qurneh, 2012; Riaz and Tanveer, 2011; Goi, 2011) stated the price is the money amount that charged for a service or product or its total value converted to a user for the benefit or use of a service or product. It refers to what customers need to pay for product or cost of products to customers. The remaining Ps are the variable cost which costs in the organization to produce and design the product includes costs to distribute products and costs to promote them. Hence, price must support this mixed elements. Prices must reflect on demand and supply relationships. In organizations, the price of a product that is too low or too high may result in loss of sale. Prices should refer to the change of fixed and variable costs, company objectives, competition, placement strategy suggestions, target segmentation groups and willingness they to pay. Expensive prices bring to higher profits. However, expensive prices can increase short-term gains but in the long run, it can bring to lower sales and profits and explain contradictory findings. Pricing can be a substitute for sales, product quality, and advertising. In most cases, prices may incentivize the company's intermediaries and salespeople, focusing on promotional strategies and value-for-money (Muala \& Qurneh, 2012; Chung \& Shin, 2008). Therefore, to enhance satisfaction of customers' service providers or organizations must to actively manage their customer perceptions of prices, such as conducting attractive prices, offering affordable prices or lower prices without lowering quality (Nakhleh, 2012; Chung \& Shin, 2008; Massoro \& Othman 2018).

\subsection{Promotion}

Promotion is an integral element of the business and is an essential tool in overall process of marketing in organizations (Shah, Javeria, \& Masood, 2018; Goi, 2011). Promotion as a sales way or technique and it must be involved with communication (promotion) to succeed in any marketing program. Promotions are identified as advertising, sales promotion, public relations, personal sales and direct marketing. It helps potential customers to know the many options of products and services that available in market. Programs of communication are essential in strategies of marketing because they play an important roles in providing the necessary advice and information, persuading customers to the merit of certain product and manage or encouraging them to take action at a given time. All activities involve such as sales, advertising, personal publicity and it all can affect their users' thinking, emotions, experiences and their purchases. Marketers must be done the communication in a way by offering consistent orders about their products and it will placed in the media which users in the target market tend to and easily use them (Muala \& Qurneh, 2012). Promotions are seen as very important as they provide persistent information, advice, and target markets. It also teaches and guides customers to take action during purchase, how they can use the product and useful results are obtained. Product advertising can be delivered by all sorts of social media such as T.V, radio, internet, magazines, newspapers and individual sales (Nunan et al., 2018).

\subsection{People}

People are an element that refers to workers who produce and deliver services within the organization. There are many services cases involving personal interactions between employees and customers and this relationship greatly influences customer perception on service quality (Muala \& Qurneh, 2012). In organization, employees are the key to the product and service delivery to their customers. Personnel are also the key elements of a centralized organization of customers and how to differentiate variables with products, services, channels and images. Customer orientation performance is unlikely if there is no cooperation and interaction from employees. This interaction become important as it affects customer perceptions of the product, the service and the organization itself. Hence, the actions of every employee usually influence the success of organizational actions and functions by enhancing communication, skills, training and learning, and the motivation they will achieve in delivering optimum value to customers (Shishi Kumar et al., 2016).

\subsection{Process}

The Process is identified as the action implementations and function due to increases the value of cheap and luxurious products to customers and it is more importantly to service than goods. Processor rates as well as service provider skills are clearly downgraded to customers and it becomes the basis of their satisfaction with purchases (Muala \& Qurneh, 2012). Therefore, management of process ensures the availability and suitability of quality. In the face of demand and simultaneous use on production management process, the balance of demand for services and supply of services is extremely difficult. The design and implementation of product elements is essential for the creation and delivery process of products smoothly (Gong \& Yi, 2018). 


\subsection{Takaful Customer Satisfaction}

Customer satisfaction is an established concept and well-known in areas of marketing, economic psychology, consumer research and economics (Aziz, Md Husin, Hussin, \& Afaq, 2019; Haji Wahab, 2018; Remli \& Rosman, 2018). The common interpretation obtained from various writers find satisfaction is the feeling generated from the evaluating process what has been received against what is expected, including the purchasing process itself and the requirements and desires of the customers associated with the purchase (Kotler et al., 1996; Oliver et al., 1997). Based on Zeithaml and Bitner (2003), satisfaction is a customer's assessment of the product or service where the products and services provided meet or do not meet their needs and expectations. Kessler (1996) stated that increased satisfaction requires a clear understanding of satisfaction and how it can be managed by service providers. Customer satisfaction also describes the measurement of the types of products and services provided by a company to meet the expectations of its customers. For some, this may be seen as an indicator for key performance of the company (KPI) (Beckers et al., 2018). In a competitive market where businesses in every organization compete for customers and this sees customer satisfaction as a major divisor and becomes an increasingly important element in business strategy. There is a large empirical literature that demonstrates the goodness of customer satisfaction for the firm. It is clear that customer's satisfactions are the key to long-run business success (Gilbert \& Veloutsou, 2006).

\section{Methods}

The population of this study is customers who have subscribing family takaful plans in selected takaful operator at least 1 years' experienced. This is because there is a period of cooling in the use of Takaful plans in accordance with product plans taken either through education plans, savings, medical cards and others. The sample size for this study were determined using Krejcie and Morgan (1970) with the minimum required sample size is 196 ( $\mathrm{N}=400)$. Overall a total of 196 questionnaires were distributed started from mid of October 2018 and 163 usable questionnaires were returned on mid of Nov 2018, yielding a response rate of $83.16 \%$.

\section{Results}

\subsection{Hypothesis 1}

Table 1 indicates the Product has a high correlation with the size (r) of 0.613 and the relationship direction is positive on Customer Satisfaction towards Takaful Operator. Besides that, p-value is 0.000 indicates a significant result which p-value below than 0.001 is significant. The positive direction relationship between these two variables shows the increase in Product will effects Customer Satisfaction towards Takaful. Therefore, the hypothesis for this research is accepted.

Table 1. Product and customer satisfaction towards takaful operator

\begin{tabular}{lll}
\hline Product & Pearson Correlation & $.613^{* *}$ \\
\hline & Sig. (2-tailed) & .000 \\
& $\mathrm{~N}$ & 163 \\
\hline
\end{tabular}

** Correlation is significant at the 0.01 level (2-tailed)

\subsection{Hypothesis 2}

Table 2 indicates the Pricing has a high correlation with the size (r) of 0.632 and the relationship direction is positive on Customer Satisfaction towards Takaful Operator. Besides that, p-value is 0.000 indicates a significant result which p-value below than 0.001 is significant. The positive direction relationship between these two variables shows the effects in Pricing will increase on Customer Satisfaction towards Takaful. Therefore, the hypothesis for this research is accepted.

Table 2. Pricing and customer satisfaction towards takaful operator

\begin{tabular}{lll}
\hline Pricing & Pearson Correlation & $.632 * *$ \\
\hline Sig. (2-tailed) & .000 \\
$\mathrm{~N}$ & 163 \\
\hline
\end{tabular}

** Correlation is significant at the 0.01 level (2-tailed). 


\subsection{Hypothesis 3}

Table 3 indicates Promotion has a high correlation with the size (r) of 0.674 and the relationship direction is positive on Customer Satisfaction towards Takaful Operator. Besides that, p-value is 0.000 indicates a significant result which p-value below than 0.001 is significant. The positive direction relationship between these two variables shows that the effects in Promotion will increase on Customer Satisfaction towards Takaful. Therefore, the hypothesis for this research is accepted.

Table 3. Promotion and customer satisfaction towards takaful operator

\begin{tabular}{lll}
\hline Promotion & Pearson Correlation & $.674^{* *}$ \\
\hline & Sig. (2-tailed) & .000 \\
& $\mathrm{~N}$ & 163 \\
\hline
\end{tabular}

** Correlation is significant at the 0.01 level (2-tailed).

\subsection{Hypothesis 4}

Table 4 indicates People have a high correlation with the size (r) of 0.696 and the relationship direction is positive on Customer Satisfaction towards Takaful Operator. Besides that, p-value is 0.000 indicates a significant result which p-value below than 0.001 is significant. The positive direction relationship between these two variables shows that the effects in People will increase on Customer Satisfaction towards Takaful. Therefore, the hypothesis for this research is accepted.

Table 4. People and customer satisfaction towards takaful operator

\begin{tabular}{lll}
\hline People & Pearson Correlation & $.696^{* *}$ \\
\hline Sig. (2-tailed) & .000 \\
& $\mathrm{~N}$ & 163 \\
\hline
\end{tabular}

** Correlation is significant at the 0.01 level (2-tailed) by variables.

\subsection{Hypothesis 5}

Table 5 indicates Process has a high correlation with the size (r) of 0.739 and the relationship direction is positive on Customer Satisfaction towards Takaful Operator. Besides that, p-value is 0.000 indicates a significant result which p-value below than 0.001 is significant. The positive direction relationship between these two variables shows that the effects in Process will increase on Customer Satisfaction towards Takaful. Therefore, the hypothesis for this research is accepted.

Table 5. Process and customer satisfaction towards takaful operator

\begin{tabular}{lll}
\hline Process & Pearson Correlation & $.739^{* *}$ \\
\hline & Sig. (2-tailed) & .000 \\
& $\mathrm{~N}$ & 163 \\
\hline
\end{tabular}

** Correlation is significant at the 0.01 level (2-tailed).

In sum, based on the hypotheses testing for each independent variable discussed the Pearson Correlation result is concluded on Table 6. 
Table 6. Pearson correlation result

\begin{tabular}{llll}
\hline & Pearson Correlation (r) & Relationship & Result of Hypotheses \\
\hline Product & 0.613 & High Correlation & H1: Accepted \\
\hline Pricing & 0.632 & High Correlation & H2: Accepted \\
\hline Promotion & 0.674 & High Correlation & H3: Accepted \\
\hline People & 0.696 & High Correlation & H4: Accepted \\
\hline Process & 0.739 & High Correlation & H5: Accepted \\
\hline 01 & & &
\end{tabular}

\section{Conclusion}

Overall, the implementation of the detailed practices have taking into account (e.g.: Product, Pricing, Promotion, People and Process) that affecting customer satisfaction contribute to a good impact on the community and the country. The use of suitable systems, knowledgeable company staff, right attitude and skill in task, aggressive promotion role, and reasonable price by maintaining the quality of products meet the customer needs as well as improve customer's positive perceptions to the Takaful Operator. Consequently, customers will benefit in terms of product offerings provided by Takaful Operator. Among them, customers have a lot of choices in choosing Takaful products that fit their prices and wants. Claims and payment processes become easier and faster in accordance with proper procedures in addition to the process being handled by knowledgeable and skilled staff. In addition, promotions that appear more aggressively make it easier for customers and the public to obtain information and knowledge about Takaful products and services. This will increase community confidence to contribute and become Takaful policyholders. The growing number of Takaful customers will also increase the company's revenue and contribute to national income. Furthermore, all of these findings make the largest contribution to the Takaful Operator in improving customer satisfaction, enhancing their performance and being more competitive advantage in marketplace.

\section{References}

Al Muala, A., \& Al Qurneh, M. (2012). Assessing the relationship between marketing mix \& loyalty through tourists satisfaction in Jordan curative tourism. American Academic \& Scholarly Research Journal, 4(2), 1.

Aziz, S., Md Husin, M., Hussin, N., \& Afaq, Z. (2019). Factors that influence individuals' intentions to purchase family takaful mediating role of perceived trust. Asia Pacific Journal of Marketing and Logistics, 31(1), 81-104. https://doi.org/10.1108/APJML-12-2017-0311

Bay, S., Petrizzi, R., \& Gill, P., (2008). The why of the buy: Consumer behavior and Fashion marketing. New York: Fairchild Books.

Beckers, S. F., Bone, S. A., Fombelle, P. W., van Doorn, J., Verhoef, P. C., \& Ray, K. R. (2018). Happy Users, Grumpy Bosses: Current Community Engagement Literature and the Impact of Support Engagement in a B2B Setting on User and Upper Management Satisfaction Customer Engagement Marketing, 141-169. https://doi.org/10.1007/978-3-319-61985-9_7

Botha, J. (2016). A holistic view of the use of corporate culture conveyed by internal marketing for enhancing stability, sustainability and consistency in service quality. Investment Management and Financial Innovations, 13(3), 248-257. https://doi.org/10.21511/imfi.13(3-1).2016.11

Cheikh, B. (2013). Abstract To Islamic Insurance Takaful. Insurance and Risk Management, 81(3), 291-304.

Chung, K.-H., \& Shin, J.-I. (2008). The relationship among e-retailing attributes, e-satisfaction and e-loyalty. Management Review: An International Journal, 3(1), 23-45.

Gilbert, G. R., \& Veloutsou, C. (2006). A cross-industry comparison of customer satisfaction. Journal of Services Marketing, 20(5), 298-308. https://doi.org/10.1108/08876040610679918

Goi, C. L. (2011). Perception of consumer on marketing mix: Male vs. female. Paper presented at the 2010 International Conference on Business and Economics Research. 
Gong, T., \& Yi, Y. (2018). The effect of service quality on customer satisfaction, loyalty, and happiness in five Asian countries. Psychology \& Marketing, 35(6), 427-442. https://doi.org/10.1002/mar.21096

Haji Wahab, M. Z. (2018). Perception of the takaful operators' performance towards customers' intention in using medical takaful card among public sector. Journal of Islamic Marketing, 9(3), 527-543. https://doi.org/10.1108/JIMA-10-2016-0076

Hassan, H. A., Abbas, S. K., \& Zainab, F. (2018). Anatomy Of Takaful. Global Scientific Journals, 6(3), 143-155.

Kaunain, F., \& Akhtar, D. S. (2016). Economic Determinant of Family Takaful: Evidence from Pakistan. Acta Islamica, 66(143), 1-35. https://doi.org/10.12816/0037640

Kessler, S. (1996). Measuring and managing customer satisfaction: going for the gold. ASQ Quality Press.

Khan, R. E. A., \& Adnan Hye, Q. M. (2014). Foreign direct investment and liberalization policies in Pakistan: An empirical analysis. Cogent Economics \& Finance, 2(1), 944667. https://doi.org/10.1080/23322039.2014.944667

Khan, S. N., \& Ali, E. I. E. (2017). The moderating role of intellectual capital between enterprise risk management and firm performance: A conceptual review. American Journal of Social Sciences and Humanities, 2(1), 9-15. https://doi.org/10.20448/801.21.9.15

Khan, Y., Hassan, T., Yi, W. M., \& Gulzar, R. (2018). A Comparative Analysis Based on Economic Factors of Students Emigration from South Asia. Asian Journal of Economics and Empirical Research, 5(2), 201-208.

Kip'ngetich, K. J., Osman, A. A., \& Ali, M. M. (2018). John Deweyl's Experimentalism Philosophy and its Claim to the Kenyan Education System. Global Journal of Social Sciences Studies, 4(1), 30-38. https://doi.org/10.20448/807.4.1.30.38

Kotler, P., Armstrong, G., Saunders, J., \& Wong, V. (1996). Principles of all Marketing: The European Edition. Prentice-Hall International, Hemel Hempstead.

Krejcie, R. V., \& Morgan, D. W. (1970). Determining sample size for research activities. Educational and Psychological Measurement, 30, 607-610. https://doi.org/10.1177/001316447003000308

Malaysia, B. N. (2017). Annual Takaful \& Insurance Report 2017.

Massoro, Z. Z., \& Othman, R. (2018). Antecedents of Citation Impact and Intention to Publish on Open Access Journals: A Case of Agricultural Research Institutes Tanzania. International Journal of Emerging Trends in Social Sciences, 4(2), 86-96. https://doi.org/10.20448/2001.42.86.96

Masud, H. (2010). Takaful: an innovative approach to insurance and Islamic Finance. University of Pennsylvania Journal of International Law, 32, 1133.

Mohammed Kamil, N., Subramaniam, M., Ali, H. E., Musah, M. B., \& Alex, A. (2018). Factors influencing the selection of unit trust funds among Malaysian retail investors. Journal of Islamic Accounting and Business Research, 9(2), 155-170. https://doi.org/10.1108/JIABR-11-2015-0057

Nakhleh, H. M. (2012). The relationship between customer relationship marketing tactics, relationship quality and customer's loyalty in mobile communication industry. Academic Research International, 3(2), 538.

Nandi, A., Das, B., \& Sable, M. (2013). Production and marketing strategy of seeds for developing countries. Journal of Crop and Weed, 9(1), 32-35.

Nunan, D., Sibai, O., Schivinski, B., \& Christodoulides, G. (2018). Reflections on "social media: Influencing customer satisfaction in B2B sales" and a research agenda. Industrial Marketing Management, 75, 31-36. https://doi.org/10.1016/j.indmarman.2018.03.009

Oliver, R. L., Rust, R. T., \& Varki, S. (1997). Customer delight: foundations, findings, and managerial insight. Journal of retailing, 73(3), 311-336. https://doi.org/10.1016/S0022-4359(97)90021-X

Pomering, A., \& Johnson, L. (2018). Building sustainability into services marketing: expanding decision-making from a mix to a matrix. Sustainability, 10(9), 2992. https://doi.org/10.3390/su10092992

Remli, N., \& Rosman, M. M. R. (2018). Firms'characteristics: A Preliminary Study of Family Takaful Demand In Malaysia. International Journal of Accounting, 3(14), 01-14.

Riaz, W., \& Tanveer, A. (2012). Marketing mix, not branding. Asian Journal of Business and Management Sciences, $1(11), 43-52$. 
Sahni, H. (2017). Analyzing Customer Experience Determinants in Apparel Buying and their impact on Purchase Intentions-A Study with specific reference to Youth in Gujarat. Aligarh Muslim University

Shah, S. A. A., Javeria, K., \& Masood, O. (2018, April). Consumption of Family Takaful affected by Microeconomic Factors: A Case Study of Islamic insurance Takaful in Pakistan. European Journal of Islamic Finance, (9), 1-6.

Shishi Kumar, P., Muhammad Awais, B., Niriender Kumar, P., \& Ariff Syah, J. (2016). Factors affecting service recovery performance and customer service employees: A study of Malaysian life insurance industry. International Journal of Productivity and Performance Management, 65(7), 898-924. https://doi.org/10.1108/IJPPM-04-2014-0060

Ying, S. S. (2017). Malaysian Insurance \& Takaful: Growth prospects favourable despite near-term moderation. Retrieved from https://www.ram.com.my/pressrelease/?prviewid=4161

Zeithaml, V., \& Bitner, M. (2003) Service Marketing: Integrating Customer Focus across the Firm. McGraw-Hill, New York. 